\title{
PENGARUH PENDIDIKAN KEWIRAUSAHAAN, PENGALAMAN \\ BERWIRAUSAHA, DAN JENIS KELAMIN TERHADAP SIKAP \\ BERWIRAUSAHA PADA MAHASISWA FAKULTAS EKONOMI UNIVERSITAS MUHAMMADIYAH SURABAYA
}

\author{
Andhika Wahyudiono, Pascasarjana Unesa \\ wahyudion21@gmail.com
}

\begin{abstract}
ABSTRAK
Penelitian ini bertujuan untuk mengetahui pengaruh pendidikan kewirausahaan, pengalaman berwirausaha, dan jenis kelamin terhadap sikap berwirausaha baik secara parsial maupun simultan. Populasi dalam penelitian ini adalah mahasiswa S1 angkatan 2012 dan 2013 Fakultas Ekonomi Universitas Muhammadiyah Surabaya terdiri dari 2 program studi yaitu akuntansi dan manajemen yang berjumlah 206 dengan sampel 103 orang. Adapun teknik pengumpulan data yang digunakan yaitu angket, wawancara, dan dokumentasi. Metode analisis yang digunakan analisis regresi linier berganda. Hasil penelitian menunjukkan bahwa pendidikan kewirausahaan, pengalaman berwirausaha, dan jenis kelamain berpengaruh signifikan terhadap sikap berwirusaha baik secara parsial maupun simultan.
\end{abstract}

Kata kunci: Pendidikan Kewirausahaan, Pengalaman Berwirausaha, Jenis Kelamin, Sikap Berwirausaha

\begin{abstract}
This study aims to determine the effect of entrepreneurship education, entrepreneurship experience, and gender of the entrepreneurship attitude either partially or simultaneously. The population in this study were students S1 class of 2012 and 2013 the Faculty of Economics, University of Muhammadiyah Surabaya consists of two majors, namely accounting and management which all are 206 students with a sample of 103 people. The data collection techniques used were questionnaires, interviews, and documentation. The method of analysis used multiple linear regression analysis. The results showed that entrepreneurship education, entrepreneurship experience, and the gender type have significant effect on the attitude of berwirusaha either partially or simultaneously.

Keywords: Entrepreneurship Education, Experience Entrepreneurship, Gender, Entrepreneurship Attitude
\end{abstract}

\section{PENDAHULUAN}

Pada saat ini Negara Indonesia masih dikatakan sebagai negara berkembang. Hal ini disebabkan oleh berbagai masalah yang terdapat di Indonesia. Misalnya pendapatan penduduk yang rendah, banyaknya pengangguran, dan kondisi ekonomi dan sosial yang tertinggal dibandingkan dengan negara maju. Banyak hal yang harus dibenahi pemerintah Indonesia untuk dapat meningkatkan kemakmuran dan kesejahteraan rakyatnya. Padatnya 
penduduk di kota besar menyebabkan sempitnya lapangan pekerjaan dan persaingan dalam mencari pekerjaan. Dalam persaingan tersebut tentunya banyak perusahaan besar yang membutuhkan tenaga ahli dengan kriteria lulusan strata 1 dan juga keahlian dalam bidangnya, persyaratan tersebut tentunya harus dipenuhi sesuai dengan keahlian dalam bidangnya.

Jumlah pengangguran intelektual yang meningkat tidak terlepas dari masalah ketebatasan kesempatan kerja bagi para lulusan perguruan tinggi. Data dari Badan Pusat Statistik menyebutkan bahwa tingkat pengangguran terbuka di Indonesia pada tahun 2014 mencapai 6,25\% atau 7,9 juta dan jumlah lulusan perguruan tinggi sebanyak 688.660 orang (495.143 Sarjana dan 193.517 Diploma). Setiap tahun pengangguran ini tetap menjadi permasalahan yang harus dicarikan penyelesaiannya. Persaingan global akhir - akhir ini seperti pemberlakuan Masyarakat Ekonomi ASEAN (MEA) semakin memperburuk kondisi pengangguran di Indonesia dimana lulusan dari perguruan tinggi Indonesia bersaing secara bebas dengan lulusan dari perguruan tinggi asing sehingga, lulusan perguruan tinggi perlu diarahkan bukan hanya sebagai pencari kerja (job seeker) tetapi juga pencipta pekerjaan (job creator).

Sikap berwirausaha mahasiswa Universitas Muhammadiyah Surabaya yang rendah ditunjukkan kurang aktifnya mereka dalam mengikuti kegiatan praktek kewirausahaan dan kegiatan seminar kewirausahaan yang diselenggarakan kampus. Oleh karena itu banyak upaya yang dilakukan perguruan tinggi terutama di Fakultas Ekonomi Universitas Muhammadiyah Surabaya untuk bisa meningkatkan sikap kewirausahaan mahasiswa melalui pendidikan kewirausahaan sebagai matakuliah umum untuk masing - masing prodi di Fakultas Ekonomi dan program kewirausahaan seperti PMW (Program Mahasiswa Wirausaha). Sehingga dapat menambah wawasan mereka dalam berwirausaha yang dapat dikembangkan kelak di masyarakat.

Kewirausahaan yang diajarkan di perkuliahan Fakultas Ekonomi Universitas Muhammadiyah Surabaya merupakan salah satu matakuliah umum yang mengajarkan teori dan praktek kewirausahaan kepada mahasiswa dengan bobot SKS (Sistem Kredit Semester) yaitu teori sebanyak 2 sks dan praktek 3 sks. Adapun tujuan dari pendidikan kewirausahaan di Universitas Muhammadiyah Surabaya adalah membekali mahasiswa agar mampu hidup mandiri dan dapat menciptakan pekerjaan yang mampu menghasilkan penghasilan terutama dengan dibekali moralitas sesama sebagaimana yang tertuang dalam semboyan kewirausahaan di Fakultas Ekonomi Universitas Surabaya

Adapun sistem pendidikan kewiruasahaan yang disusun pihak Fakultas Ekonomi Universitas Muhammadiyah Surabaya dalam mengenalkan kewirausahaan pada mahasiswa yaitu melalui kegiatan pembelajaran di kampus pada semester 3 dengan pembahasan teori kewirausahaan dengan ditunjang fasilitas belajar yang mendukung proses pembelajaran kewirausahaan tersebut. Pada akhir perkuliahan semester 3 mahasiswa diberikan tugas untuk membuat desain kerangka usaha untuk diaplikasikan desain tersebut pada semester 4 yaitu dalam bentuk bazzar. Adanya pembelajaran kewirausahaan yang dirancang pada semester 3 dan 4 bertujuan untuk memberikan wawasan dan keterampilan berwirausaha pada mahasiswa Fakultas Ekonomi Universitas Muhammadiyah Surabaya.

Pendidikan kewirausahaan berperan penting dalam perkembangan 
wawasan dan keterampilan seseorang untuk mandiri dalam berusaha dengan berbagai potensi yang dimiliki. Pendidikan kewirausahaan menurut Tung (2011) mengatakan bahwa pendidikan kewirausahaan adalah proses transmisi pengetahuan dan keterampilan kewirausahan kepada siswa untuk membantu mereka dalam memanfaatkan pelauang bisnis. Pendapat ini diperkuat oleh Saroni (2012) yang menjelaskan bahwa pendidikan kewirausahaan adalah program pendidikan yang menggarap aspek kewirausahaan sebagai bagian terpenting dalam pembekalan kompentensi anak didik.

Wibowo (2011) pendidikan kewirausahaaan merupakan upaya menginternalisasikan jiwa dan mental kewirausahaan baik melalui institusi pendidikan maupun institusi lain seperti lembaga pelatihan, training dan sebagainya. Dilanjutkan Saroni (2012) menyatakan bahwa pendidikan kewirausahaan adalah program pendidikan yang menggarap aspek kewirausahaan sebagai bagian penting dalam pembekalan komptensi anak didik. Pendidikan kewirausahaan dirancang untuk menanamkan kompetensi, keterampilan dan nilai - nilai yang diperlukan dalam mengenali peluang bisnis, mengatur dan memulai usaha baru (Brown dalam Izedonmi \& Okafor, 2010). Hal ini diperkuat Lestari \& Wijaya (2012) Pendidikan kewirausahaan tidak hanya memberikan landasan teoritis mengenai konsep kewirausahaan tetapi membentuk sikap, perilaku, dan pola pikir (mindset) seorang wirausahawan (entrepreneur).

Pengaruh pendidikan kewirausahaan selama ini telah dipertimbangkan sebagai salah satu faktor penting untuk menumbuhkan dan mengembangkan hasrat, jiwa dan perilaku berwirausaha di kalangan generasi muda (Kourilsky \& Walstad, 1998). Senada Hisrich \& Peters (1998) pendidikan penting bagi wirausaha, tidak hanya gelar yang didapatkannya saja, namun pendidikan juga mempunyai peranan yang besar dalam membantu mengatasi masalah-masalah dalam bisnis seperti keputusan investasi dan sebagainya.

Hasil penelitian Gallant et al. (2010) sekarang ini, kewirausahaan dipandang sebagai sumber penting bagi pertumbuhan ekonomi dan pendidikan kewirausahaan merupakan komponen penting dalam penciptaan dan pengembangan sikap kewirausahaan. Hasil penelitian Lewis \& Massey (2003) tujuan pendidikan adalah untuk mengembangkan individu (terutama anak muda) dengan seperangkat keterampilan dan sikap yang akan memungkinkan mereka untuk menjadi pencipta kerja. Hasil penelitian Hegarty (2006) membuktikan bahwa kelompok belajar dalam pendidikan kewirausahaan yang disebut NICENT (Northern Ireland Centre for Entrepreneurship) dapat meningkatkan sikap positif kewirausahaan di Irlandia Utara. Adanya pernyataan dari beberapa peneliti diatas mengenai pentingnya pendidikan kewirausahaan untuk diterapkan bertujuan memberikan dukungan dalam meningkatkan pemahaman dan keterampilan seseorang dalam berwirausaha, terutama dalam lingkup kampus yang merupakan dasar dari pemahaman kewirausahaan baik secara teroi maupun praktik.

Adanya pendidikan kewirausahaan yang dilaksanakan di kampus memberikan dorongan bagi mahasiswa untuk mengasah pengetahuan dan keterampilan dalam berwirausaha, sehingga membentuk pengamalan berwirausaha mereka. Namun peran pendidikan kewirausahaan tidaklah cukup dalam membentuk sikap kewirausahaan mahasiswa. Pengalaman berwirausaha mahasiswa Fakultas Ekonomi Universitas Muhammadiyah Surabaya diperoleh dari peran lingkungan keluarga yang sebagian besar berkecimpung dalam dunia 
usaha atau wiraswasta. Dilanjutkan peran lingkungan sosial yang besar mereka hidup dilingkungan pedagang dan ikut berdagang, sehingga kemungkinan besar pengalaman berwirausaha mereka lebih banyak dan survive dalam berwirausaha.

Pengalaman berwirausaha berperan penting dalam menambah pengetahuan dan kemampuan dalam keahlian dan keterampilan dalam berwirausaha. Hal ini dikarenakan pengalaman memberikan pengetahuan awal seseorang sebelum bertindak dalam memaksimalkan usahanya sehingga tanpa disadari orang tersebut sudah memiliki kemampuan memprediksi hasil yang diperoleh atas tindakan dalam usahanya. Adapun pengalaman berwirausaha menurut Douglas (dalam Heinrichs, 2013) entreprenurial experience yaitu pengalaman seseorang individu dalam berwirausaha dan mengerti sistem dalam menjalankan usaha. Sedangkan Nuskhi \& Setiana (2004), menyatakan aspek pengalaman berusaha melalui keberanian mengambil resiko dengan mengadakan kegiatan belajar yang tidak hanya menyampaikan pesan secara teoritis, tetapi anggota diberi kesempatan untuk mencoba. Gurbuz \& Aykol (2008) menegaskan bahwa pendidikan, pengalaman dan pembekalan kewirausahaan sejak usia dini dapat meningkatkan potensi seseorang untuk menjadi wirausahawan, disamping dukungan pihak akademik, sosial dan lingkungan usaha.

Menurut Zimmer dalam Harris et al.(2008) yang menyatakan bahwa entrepreneurship bukan ciri genetik tetapi "pembelajaran keterampilan", maka penting untuk mempelajari pengaruh pengalaman seseorang pada pengembangan sikap menjadi wirausaha. Sedangkan Staw dalam. Dilanjutkan Suharti \& Sirine (2011) yang menyatakan bahwapembekalan pendidikan dan pengalaman kewirausahaan pada seseorang sejak usia dini dapat meningkatkan potensi seseorang untuk menjadi wirausahawan.

Hasil penelitian Sowmya et al. (2010) menjelaskan bahwa karakteristik siswa dan pengalaman kewirausahaan yang ditemukan terkait dengan sikap kewirausahaan. Ditambahkan Politis (2008) pengalaman sebagai sumber belajar dan pengaruhnya terhadap keterampilan, preferensi dan sikap wirausaha. Dilanjutkan Harris \& Gibson (2008) karakteristik siswa dan pengalaman kewirausahaan yang ditemukan berhubungan dengan sikap kewirausahaan. Hal ini membuktikan bahwa pengalaman berwirausaha meruapkan faktor penting dalam mengembangkan sikap berwirausaha seseorang terutama dalam hal perkembangan pengetahuan dan keterampilan seseorang untuk berwirausaha.

Peran pendidikan kewirausahaan dan pengalaman berwirausaha memberikan dorongan besar bagi mahasiswa untuk mengembangkan kemampuan meraka dalam berwirausaha. Adapun mahasiswa perempuan di Fakultas Ekonomi Universitas Muhammadiyah Surabaya cenderung lebih aktif dalam proses pembelajaran kewirausahaan yang sedang berlangsung. Terutama dalam kegiatan bazzar mereka cenderung memiliki inisiatif usaha yang tinggi untuk menciptakan usaha seperti usaha makanan, minumam dan desain grafis. Hal ini didukung juga dari pengalaman berwirausaha mereka yang diperoleh dari lingkungan keluarga yang notabene bekerja sebagai pedagang dan juga keikutsertaan mereka dalam kegiatan organisasi wirausaha seperti Koperasi Mahasiswa yang diselenggarakan pihak kampus.

Hasil penelitian Packham et al. (2010) pendidikan kewirausahaan memiliki dampak positif pada sikap kewirausahaan mahasiswa Perancis dan Polandia yang ditunjukkan pada mahasiswa perempuan lebih besar dalam 
memahami manfaat pengalaman, pendidikan kewirausahaan pada sikap kewirausahaan daripada mahasiswa laki-laki. Sedangkan menurut Swomya et al. (2010) menunjukkan bahwa siswa perempuan muda di Dubai berperan positif dalam mengembangkan sikap berwirausaha mereka.

Dari penjelasan di atas penelitian ini bertujuan untuk menganalisis pengaruh pendidikan kewirausahaan, pengalaman berwirausaha, dan jenis kelamin terhadap sikap berwirausahan pada Mahasiswa Fakultas Ekonomi Universitas Muhammadiyah Surabaya.

\section{METODE PENELITIAN}

Penelitian ini menggunakan pendekatan kuantitatif dengan menggambarkan regresi linier berganda antara dua variabel bebas dan variabel terikat. Dalam penelitian ini, variabel terikat yaitu sikap berwirausaha $(\mathrm{Y})$ dan variabel bebas yaitu pendidikan kewirausahaan $\left(\mathrm{X}_{1}\right)$, pengalaman berwirausaha $\left(\mathrm{X}_{2}\right)$ dan jenis kelamin (D) Populasi dalam penelitian ini adalah mahasiswa Fakultas Ekonomi angkatan 2012 - 2013 berjumlah 203 orang sedangkan sampel diambil sebanyak 107 orang. Teknik sampling yang digunakan dalam penelitian ini menggunakan proportional random sampling.

Metode pengumpulan data yang digunakan dalam penelitian ini adalah angket, wawancara dan dokumentasi. Kuesioner yang digunakan mengungkapkn variabel pendidikan kewirausahaan, pengalaman berwirausaha, jenis kelamin dan sikap berwirausaha. Metode analisis data yang digunakan dalam penelitian ini adalah analisis deskriptif dan regresi berganda. Analisis deskriptif digunakan untuk mengetahui kondisi pendidikan kewirausahaan, pengalaman berwirausaha, jenis kelamin, dan sikap berwirausaha. Sedangkan analisis regresi digunakan untuk mengetahui besarnya pengaruh antara variabel bebas dengan variabel terikatbaik secara parsial maupun secara simultan.

\section{HASIL PENELITIAN DAN PEMBAHASAN}

Berdasarkan uji normalitas nilai residual adalah uji statistik nonparametrik Kolmogorov-Smirnov. Sugiyono (2013) menjelaskan jika hasil Kolmogorov-Smirnov menunjukkan nilai signifikan diatas 0,05 maka data residual terdistribusi dengan normal. Sedangkan jika hasil Kolmogorov-Smirnov menunjukkan nilai signifikan dibawah 0,05 maka data residual terdistribusi tidak normal, dengan nilai Asymp. Sig (2-tailed) diketahui bahwa nilai signifikasi sebesar 0,075 lebih besar dari 0,05, berarti dapat disimpulkan data yang di uji berdistribusi normal. Hasil uji Multikolinieritas menjelaskan bahwa nilai tolerance dan VIF yang dihasilkan oleh variabel pendidikan kewirausahaan $\left(\mathrm{X}_{1}\right)$ adalah 0,305 untuk nilai tolerance (kurang dari angka 1) dan nilai VIF adalah 3,277 (kurang dari angka 10), sedangkan variabel pengalaman berwirausaha $\left(\mathrm{X}_{2}\right)$ adalah 0,305 untuk nilai tolerance (kurang dari angka 1) dan nilai VIF adalah 3,277 (kurang dari angka 10) sehingga antara variabel bebas tidak terjadi multikolinieritas.

Hasil uji Heterokedastisitasadalah suatu keadaan dimana masing - masing kesalahan atau residu yang mempunyai varian yang berbeda dan dimaksudkan untuk menguji apakah varians dari kesalahan pengganggu tidak konstan untuk 
semua variabel bebas. Model regresi yang baik adalah jika terjadi homokedastisitas atau tidak terdapat heterokedastisitas. Metode korelasi yang dipergunakan dalam penelitian ini adalah korelasi rank spearma.Hasil uji heterokedastisitas menunjukkantingkat signifkasi melebihi $5 \%$ yaitu 0,610 pada variabel pendidikan kewirausahaan $\left(\mathrm{X}_{1}\right)$, 0,560 pada variabel pengalaman berwirausaha $\left(\mathrm{X}_{2}\right)$, dan 0,524 pada variabel jenis kelamin (D) maka dapat dikatakan bahwa antara variabel bebas dengan residual tidak terjadi heterokedastisitas.

Hasil uji linieritas ditujukan untuk mengetahui apakah sebaran data penelitian mempunyai sebaran yang sesuai dengan garis linier atau tidak dengan melihat tabel anova pada deviation from linearity. Jika nilai deviation from linearity $>0,05$ maka antara variabel bebas dan variabel terikat mempunyai hubungan linier, dan sebaliknya jika deviation from linearity $<0,05$ maka tidak mempunyai hubungan linear. Hasil uji linieritas menunjukkan bahwa nilai signifikasi variabel pendidikan kewirausahaan yaitu 0.089 yang menandakan bahwa nilai tersebut lebih besar dari 0.05 , yang artinya terdapat hubungan linier secara signifikan antara variabel pendidikan kewirausahaan $\left(\mathrm{X}_{1}\right)$ dengan sikap berwirausaha $(\mathrm{Y})$. sedangkan nilai signifikasi variabel pengalaman berwirausaha yaitu 0.836 yang menandakan bahwa nilai tersebut lebih besar dari 0.05 , yang artinya terdapat hubungan linier secara signifikan antara variabel pengalaman berwirausaha $\left(\mathrm{X}_{2}\right)$ dengan sikap berwirausaha $(\mathrm{Y})$. Berdasarkan hasil uji linieritas pada masing - masing variabel $\mathrm{X}$ dengan variabel $\mathrm{Y}$ terjadi hubungan linieritas karena nilai signifikasinya lebih besar dari 0.05 , sehingga dalam penelitian ini tidak terjadi masalah linieritas.

Model regresi linier berganda yang diperoleh berdasarkan hasil penelitian dapat dituliskan dalam bentuk persamaan sebagai berikut

$$
\mathrm{Y}=\mathbf{1 4 , 5 4 2}+\mathbf{0 , 2 6 5} \mathrm{X}_{1}+\mathbf{0 , 4 2 9} \mathrm{X}_{\mathbf{2}}+\mathbf{1 , 6 5 0} \mathrm{D}+\mathrm{ei}
$$

Berdasarkan persamaan regresi tersebut ketiga variabel bebas memiliki koefisien regresi dengan arah positif. Hal ini berarti semakin baik pendidikan kewirausahaan, pengalaman berairausaha, dan jenis kelamin maka semakin baik sikap berwirausaha. Dari persamaan tersebut dapat dijelaskan yaitu konstanta (a) yang dihasilkan sebesar 14,542 hai ini menunjukkan bahwa besarnya sikap berwirausaha adalah 14,542 jika variabel pendidikan kewirausahaan, pengalaman berwirausaha dan jenis kelamin adalah nol konstan,

Koefisien regresi variabel pendidikan kewirausahaan yang dihasilkan sebesar 0,265 hal ini menunjukan bahwa setiap perubahan variabel pendidikan kewirausahaan $\left(\mathrm{X}_{1}\right)$ akan berpengaruh positif pada sikap berwirausaha $(\mathrm{Y})$. Nilai koefisien regresi positif menunjukkan pengaruh yang timbul searah, dimana naiknya variabel pendidikan kewirausahaan $\left(\mathrm{X}_{1}\right)$ sebesar satu satuan maka sikap berwirausaha akan naik sebesar satu dengan asumsi variabel pengalaman berwirausaha dan jenis kelamin adalah konstan. Hasil statistik menunjukkan adanya pengaruh pendidikan kewirausahaan $\left(\mathrm{X}_{1}\right)$ terhadap sikap berwirausaha $(\mathrm{Y})$ ditunjang dengan hasil penelitian dari beberapa ahli yaitu; hasil penelitian Sascha \& Dirk (2009) menyatakan bahwa pendidikan kewirausahaan dapat meningkatkan sikap berwirausaha. Hasil penelitian Gallant et al (2010) menunjukkan kewirausahaan dipandang sebagai sumber penting bagi pertumbuhan ekonomi dan pendidikan merupakan komponen penting dalam penciptaan dan pengembangan sikap kewirausahaan pada siswa di Dubai. 
Hasil penelitian Souitaris et al, (2007) menyatakan bahwa pendidikan kewirausahaan meningkatkan sikap berwirausaha secara keseluruhan. Hasil penelitian Borasi \& Finnigan, (2011) menyatakan hasil identifikasi sikap dan perilaku berwirausaha berkontribusi dalam mendorong keberhasilan pendidikan kewirausahaan. Hasil penelitian Lee \& Wong, (2003) menunjukkan pendidikan kewirausahaan mendorong pertumbuhan usaha baru dengan survey 15.000 mahasiswa di Singapura, terutama dalam hal perkembangan sikap berwirausaha.

Hasil peneltiian Hegarty (2006) menjelaskan kelompok belajar dalam pendidikan kewirausahaan yang disebut NICENT (Northern Ireland Centre for Entrepreneurship) dalam pendidikan kewirausahaan dapat meningkatkan sikap kewirausahaan di Irlandia Utara. Hasil penelitian Carey \& Naudin (2006) menyatakan pendidikan kewirausahaan memberikan gambaran lansung pada perkembangan sikap dan pelatihan dalam industry kreatif. Hasil penelitian Petridou \& Glaveli (2008) menunjukkan pelatihan yang diikuti wanita Yunani mendukung kemampuan sikap berwirausaha mereka.

Hasil penelitian Zhao (2005) kewirausahaan dalam praktek organisasi memberikan kontribusi terhadap pengembangan sikap berwirausaha. Hasil penelitian Packham et al (2010) pendidikan kewirausahaan berdampak positif pada sikap kewirausahaan mahasiswa Perancis dan Polandia. Hal ini ditunjukkan mahasiswa perempuan lebih memahami manfaat pengalaman belajar, dibandingkan mahasiswa laki-laki di Jerman. Hasil penelitian Lewis \& Massey (2003) pendidikan kewirausahaan dapat mengembangkan potensi individu (terutama anak muda) dengan seperangkat keterampilan yang bertujuan mengembangkan sikap berwirausaha mereka untuk menjadi pencipta kerja.

Hasil penelitian Jones et al (2011) menunjukkan pendidikan kewirausahaan mampu menumbuhkembangkan sikap dan motivasi siswa Polandia. Hasil penelitian Matlay (2008) menunjukkan pendidikan kewirausahaan mendukung keterampilan berwirausaha dalam mengembangkan sikap berwirausaha seseorang. Hasil penelitian Ain (2013) menunjukkan pengaruh yang positif dan signifikan antara pendidikan dan pelatihan kewirausahaan terhadap sikap kewirausahaan peserta didik SMK N 1 Cerme. Semakin tinggi pendidikan \& pelatihan kewirausahaan dilaksanakan, maka akan semakin tinggi sikap kewirausahaan peserta didik. Sebaliknya, semakin rendah pendidikan \& pelatihan kewirausahaan dilaksanakan, maka akan semakin rendah sikap kewirausahaan peserta didik.

Adapun hasil temuan penelitian ditunjukkan dari indikator pendidikan kewirausahaan yaitu;

1. Tujuan pendidikan pada indikator ini menunjukkan hasil temuan bahwa mahasiswa memiliki keyakinan yang tinggi untuk mempelajari mata kuliah kewirausahaan dengan harapan mengetahui lebih dalam lagi mengenai dunia usaha karena tujuan pembelajaran kewirausahaan mengajarkan mahasiswa untuk kreatif dan inovatif untuk menjalankan usahanya, mahasiswa merasakan manfaat yang besar pada saat mengikuti mata kuliah kewirausahaan karena ilmu kewirausahaan menanamkan karakter wirausaha dalam diri mahasiswa sehingga mereka dapat mengembangkan potensi diri mereka dalam berwirausaha, mahasiswa memiliki pemahaman yang lebih mengenai dunia usaha karena ilmu kewirausahaan disampaikan dengan teori maupun praktek sehingga membuat mereka termotivasi, mahasiswa 
termotivasi menjadi wirausaha karena materi disampaikan secara kontekstual, dan mahasiswa memiliki motivasi yang tinggi untuk mengikuti kegiatan ekstra yang berkaitan dengan kewirausahaan karena mahasiswa dapat sharring pendapat maupun informasi mengenai dunia usaha.

2. Sarana dan prasarana pada indikator ini menunjukkan hasil temuan bahwa mahasiswa kurang dapat menggunakan lab kewirausahaan yang disediakan kampus untuk kegiatan kewirausahaan karena kondisi lab yang digunakan secara bergantian untuk setiap kelas, mahasiswa kurang dapat menggunakan fasilitas belajar kewirausahaan di dalam kelas karena jam belajar yang terbatas, mahasiswa kurang dapat menggunakan fasilitas internet untuk memperoleh referensi mengenai ilmu kewirausahaan karena bandwith acces internet yang terbatas sehingga dibatasi dengan kuota jumlah pengguna, dan mahasiswa kurang dapat memperoleh referensi sumber bacaan atau buku yang lengkap mengenai ilmu kewirausahaan karena masih menggunakan referensi buku lama sehingga perlu adanya update referensi buku mengenai ilmu kewirausahaan.

3. Materi pengajaran dalam indikator ini menunjukkan hasil temuan bahwa mahasiswa sangat tertarik dengan matakuliah kewirausahaan mampu memberikan gambaran dan materi yang berkaitan dengan dunia usaha karena banyak mengungkapkan perjalanan tokoh wirausaha sehingga menjadi motivasi, mahasiswa sangat memperoleh manfaat yang besar setelah mengikuti matakuliah kewirausahaan karena mereka dapat beradu argumen dan bertukar informasi mengenai dunia usaha, dan mahasiswa tertarik dengan matakuliah kewirausahaan karena membantu dalam memahami dunia usaha karena dalam proses pembelajarannya disajikan secara kontekstual dan pada akhir semester dilakukan praktek kewirausahaan.

4. Metode Pengajaran dalam indikator ini menunjukkan hasil temuan bahwa mahasiswa cukup tertarik mempelajari matakuliah kewirausahaan karena banyak melakukan praktek kewirausahaan dengan membuat bisnis plan, mahasiswa cukup tertarik mempelajari matakuliah kewirausahaan karena disajikan dalam secara kontekstual karena banyak memberikan gambaran atau contoh usaha dalam dunia usaha sebenarnya, dan mahasiswa cukup termotivasi dalam mempelajari matakuliah kewirausahaan karena banyak memberikan gambaran dan contoh tokoh wirausaha karena mereka dapat mengambil nilai - nilai penting untuk diapresiasikan dalam dunia usaha yang sebenarnya.

Hasil temuan penelitian ditunjukkan dari indikator sikap berwirausaha yaitu ;

1. Pemanfaatan peluang dalam indikator ini menunjukkan hasil temuan bahwa mahasiswa cukup mampu melihat peluang usaha yang ada disekitar lingkungan karena pembelajaran kewirausahaan dikampus memberikan informasi mengenai kegiatan usaha yang sedang berkembang, serta mahasiswa memiliki cukup motivasi untuk memulai bisnis dengan melihat peluang usaha yang ada karena adanya sharring dan bimbingan dari tenaga pengajar untuk mengembangkan usahanya.

2. Berorientasi pada hasil dalam indikator ini menunjukkan hasil temuan bahwa mahasiswa kurang memiliki dorongan atau minat yang kuat untuk berwirausaha karena kurang memahami dasar - dasar mengelola suatu usaha dan mahasiswa kurang memiliki insiatif untuk mengembangkan usaha karena 
minimnya jaringan usaha yang dimiliki pihak kampus.

3. Bekerja keras dalam indikator ini menunjukkan hasil temuan bahwa mahasiswa cukup memiliki semangat yang tinggi dalam berwirausaha karena adanya dukungan dari tenaga pendidik untuk membimbing mereka dalam mempelajari ilmu kewirausahaan dan mahasiswa memiliki cukup semangat tidak mudah putus asa dalam menjalankan usaha karena mahasiswa selalu sharring dengan tenaga pengajar mengenai persoalan yang ditemui dalam pembelajaran kewirausahaan.

4. Pengambilan resiko dalam indikator ini menunjukkan temuan bahwa mahasiswa sangat berani mengambil resiko untuk membangun usaha karena mereka memanfaat fasilitas belajar yang disediakan kampus sehingga dapat membangun keberanian berwirausaha mereka dan mahasiswa sangat yakin bahwa resiko merupakan tantangan dalam mengembangkan usaha karena mereka memperbaiki setiap kesalahan atau kekurangan dalam berwirausaha dengan cara berkonsultasi dengan tenaga pengajar kewirausahaan di kampus.

5. Percaya diri dalam indikator ini menunjukkan hasil temuan bahwa mahasiswa memiliki keyakinan yang tinggi untuk berwirausaha karena ilmu kewirausahaan dapat dipelajari dengan baik dengan memanfaatkan sumber informasi kewirausahaan yang disediakan kampus dan mahasiswa memiliki sikap positif yang tinggi untuk memulai usaha karena adanya dukungan dari tenaga pengajar dan teman sekampus dalam mengembangkan potensi wirausaha yang dimiliki dengan melakukan sharring pendapat dan bertukar informasi ilmu kewirausahaan.

Berdasarkan pembahasan tersebut untuk mencapai sikap berwirausaha yang tinggi perlu memperhatikan ketersedian sarana dan prasarana belajar pada pendidikan kewirausahaan yang diselenggarakan oleh pihak kampus.

Koefisien regresi variabel pengalaman berwirausaha yang dihasilkan sebesar 0,429 hal ini menunjukan bahwa setiap perubahan variabel pengalaman berwirausaha $\left(\mathrm{X}_{2}\right)$ akan berpengaruh positif pada sikap berwirausaha (Y). Nilai koefisien regresi positif menunjukkan pengaruh yang timbul searah, dimana naiknya variabel pengalaman berwirausaha $\left(\mathrm{X}_{2}\right)$ sebesar satu satuan maka sikap berwirausaha akan naik sebesar satu dengan asumsi variabel pendidikan kewirausahaan dan jenis kelamin adalah konstan.

Hasil statistik menunjukkan adanya pengaruh pengalaman berwirausaha $\left(\mathrm{X}_{2}\right)$ terhadap sikap berwirausaha $(\mathrm{Y})$ ditunjang dengan hasil penelitian dari beberapa ahli yaitu; hasil penelitian Bohner \& Wanke (2001) menjelaskan bahwa sikap merupakan hasil dari pengalaman masa lalu atau perilaku masa lalu. Hasil penelitian Heilman \&Chen (2003) menemukan pengalaman berwirausaha perempuan dan kelompok-kelompok non Kaukasia yang kurang dibandingkan laki-laki Kaukasia yang ditunjukkan melalui sikap berwirausaha. Hasil penelitian Politis (2008) menunjukkan pengalaman awal sebagai sumber belajar yang berpengaruh terhadap sikap berwirausaha yang bertujuan untuk mengembangkan potensi yang dimiliki secara terukur dan terarah. Hasil penelitian Basu \& Virick (2007) menunjukkan pengalaman di masa lalu dalam membuka bisnis baru akan berpengaruh terhadap attitudes towards dan perceived behavioral seseorang yang bertujuan sebagai pilihan mereka berkarir di bidang kewirausahaan.

Hasil penelitian Harris \& Gibson (2008) karakteristik siswa dan pengalaman kewirausahaan yang ditemukan berhubungan dengan sikap 
kewirausahaan. Hasil penelitian Davey et al (2011) menyatakan siswa dari negara berkembang lebih mungkin untuk membayangkan karir masa depan sebagai pengusaha dan lebih positif terhadap kewirausahaan daripada rekan-rekan mereka di Eropa. Hal ini didasarkan pada sejauh mana pengalaman berwirausahayang bervariasi antar masing-masing negara.

Adapun hasil temuan penelitian ditunjukkan dari indikator pengalaman berwirausaha yaitu;

1. Lingkungan keluarga dalam indikator ini menjelaskan mahasiswa mengenal dunia usaha dengan adanya latar belakang keluarga yang menggeluti kegiatan usaha karena anggota keluarga membantu mereka dalam membimbing untuk menjadi wirausaha seperti ikutserta dalam mengelola usaha, mahasiswa terbimbing untuk melakukan usaha dengan adanya dukungan keluarga karena dukungan moral memberikan mereka kesempatan untuk membangun keberanian berwirausaha, dan mahasiswa sangat terbantu dengan peran keluarga yang mengajarkan mereka untuk berwirausaha karena mereka diajarkan secara langsung cara menjalankan usaha dan mengembangkan usaha yang sudah digeluti oleh keluarga.

2. Lingkungan social dalam indikator ini menunjukkan hasil temuan bahwa mahasiswa terdorong untuk berwirausaha karena pengaruh lingkungan dimana mereka tinggal karena lingkungan mereka tinggal memberikan peluang untuk mempelajari dunia usaha yang sesungguhnya, mahasiswa termotivasi untuk berwirausaha karena adanya seminar kewirausahaan yang dilakukan dilingkungan sekitar karena mereka dapat sharring pendapat dengan pakar ahli maupun masyarakat sekitar mengenai cara mendirikan usaha sampai dengan mengembangkan usaha, dan mahasiswa memperoleh banyak informasi kewirausahaan dari lingakungan sekitar karena banyak sumber media cetak maupun elektronik yang memberikan informasi kewirausahaan yang baru.

3. Lingkungan pendidikan menunjukkan temuan yaitu mahasiswa Fakultas Ekonomi kurang dapat memaksimalkan informasi mengenai ilmu kewirausahaan baik yang diajarkan dalam bentuk teori maupun praktek. Hal ini dikarenakan adanya keterbatasan waktu dalam belajar yang dilaksanakan di kampus.

Hasil temuan penelitian ditunjukkan dari indikator sikap berwirausaha yaitu;

1. Pemanfaatan peluang dalam indikator ini menunjukkan hasil temuan bahwa mahasiswa cukup mampu melihat peluang usaha yang ada disekitar lingkungan karena lingkungan sebagian besar adalah pemilik usaha sehingga mereka dapat menfaatkannya untuk menggali pengetahuan mereka tetang dunia usaha, serta mahasiswa memiliki cukup motivasi untuk memulai bisnis dengan melihat peluang usaha yang ada karena baik dilingkungan keluarga maupun masyarakat memiliki beragama usaha dengan jaringan usaha yang luas.

2. Berorientasi pada hasil dalam indikator ini menunjukkan hasil temuan bahwa mahasiswa kurang memiliki dorongan atau minat yang kuat untuk berwirausaha karena lingkungan tidak menyediakan data secara lengkap mengenai cara membangun usaha yang besar, dan mahasiswa kurang memiliki insiatif yang tinggi untuk mengembangkan usaha karena lingkungan usaha cenderung menggambarkan untuk mempertahankan usaha bukan 
mengembangkan usaha secara besar.

3. Bekerja keras dalam indikator ini menunjukkan hasil temuan bahwa mahasiswa cukup memiliki semangat yang tinggi dalam berwirausaha karena lingkungan cenderung menggambarkan aktivitas menjalankan usaha, dan mahasiswa memiliki cukup semangat tidak mudah putus asa dalam menjalankan usaha karena lingkungan memberikan kesempatan sharring pendapat mengenai persoalan berwirausaha.

4. Pengambilan resiko dalam indikator ini menunjukkan hasil temuan bahwa mahasiswa sangat berani mengambil resiko untuk membangun usaha karena mereka cenderung meniru atau melihat rekam sejarah orang dalam lingkungan tersebut yang menjalani usaha dari bawah hingga sukses, dan mahasiswa sangat yakin bahwa resiko merupakan tantangan dalam mengembangkan usaha karena pengalaman dilapangan yang mengembangkan karakter berwirausaha mereka.

5. Percaya diri dalam indikator ini menunjukkan hasil temuan bahwa mahasiswa memiliki keyakinan yang tinggi untuk berwirausaha karena lingkungan dimana mereka tinggal banyak mengapresiasikan kegiatan usaha harus dijalankan dengan tekun walaupun memperoleh hasil yang kecil dan mahasiswa memiliki sikap positif yang tinggi untuk memulai usaha karena mereka termotivasi dengan lingkungan yang mempu bertahan dan mengembangkan usaha.

Berdasarkan pembahasan tersebut untuk mencapai sikap berwirausaha yang tinggi perlu memperhatikan aspek lingkungan pendidikan dalam mendukung terbentuknya sikap kewirausahaan yang seharusnya.

Nilai signifikasi variabel jenis kelamin (Y) sebesar 0,032. Nilai ini menunjukkan bahwa adanya perbedaaan sikap berwirausaha mahasiswa antara jenis kelamin laki - laki dan perempuan, dimana mahasiswa perempuan lebih tinggi sikap berwirausaha dibandingkan mahasiswa laki - laki. Adapun hasil penelitian yang menunjang variabel jenis kelamin (Y) yaitu hasil penelitian Furdas \& Kohn (2010) menyatakan perbedaan gender yaitu didasarkan pada jenis kelamin laki - laki dan perempuan menetukan sikap berwirausaha di Jerman. Hasil penelitian Amine \& Staub (2009) menyatakan jenis kelamin mempengaruhi sikap dan perilaku berwirausaha di Sub Sahara Afrika. Hasil penelitian Kundu \& Rani (2008) menunjukkan bahwa perbedaan yang signifikan antara peserta lakilaki dan perempuan terhadap sikap berwirausaha dan secara signifikan factor gender juga menentukan EAO (Enterpreneur Attitude Orientation) seseorang.

Hasil penelitian Sowmyaet al. (2010) menyatakan siswa perempuan muda di Dubai menyatakan peran perguruan tinggi mendorong dalam mengembangkan sikap berwirausaha mereka. Hasil penelitian Petridou et al.(2009) menunjukkan perempuan memiliki sikap berwirausaha yang kuat. Hal ini ditunjukkan dari sikap perempuan dalam memperoleh pengetahuan, terutama dalam mengembangkan keterampilan, untuk menghadapi persaingan karir dan jaringan dengan bisnis local pada tingkat yang jauh lebih tinggi daripada rekan-rekan pria mereka. Selain itu, perempuan memiliki keterampilan yang penting lebih tinggi dalam kegiatan kewirausahaan seperti dalam keterampilan komunikasi dibandingkan dengan laki-laki.

Hasil temuan penelitian ditunjukkan dari indikator sikap berwirausaha yaitu; 
1. Pemanfaatan peluang dalam indikator ini menunjukkan hasil temuan bahwa mahasiswa cukup mampu melihat peluang usaha yang ada disekitar lingkungan karena mereka mempunyai pemikiran yang berbeda dalam mengambil keputusan atas kesempatan usaha yang ada, serta mahasiswa memiliki cukup motivasi untuk memulai bisnis dengan melihat peluang usaha yang ada karena adanya komunikasi antara mahasiswa laki - laki dan perempuan untuk saling tukar informasi mengenai kesempatan untuk menciptakan usaha.

2. Berorientasi pada hasil dalam indikator ini menunjukkan hasil temuan bahwa mahasiswa kurang memiliki dorongan atau minat yang kuat untuk berwirausaha karena informasi yang diberikan terbatas serta kurangnya waktu untuk melakukan diskusi mengenai usaha yang akan didirikan dan mahasiswa kurang memiliki insiatif yang tinggi untuk mengembangkan usaha karena mereka cenderung sekedar ikut - ikutan dalam menjalankan usaha sehingga inisiatif untuk mengembangkan usaha tidak terpikirkan secara matang.

3. Bekerja keras dalam indikator ini menunjukkan hasil temuan bahwa mahasiswa cukup memiliki semangat yang tinggi dalam berwirausaha karena mereka mau mempelajari kewirausahan dengan cara berbagi solusi maupun masalah usaha yang dihadapi bersama teman dan mahasiswa memiliki cukup semangat tidak mudah putus asa dalam menjalankan usaha karena mereka selalu sharring mengenai persoalan yang ditemui dalam berwirausaha.

4. Pengambilan resiko dalam indikator ini menunjukkan hasil temuan bahwa mahasiswa sangat berani mengambil resiko untuk membangun usaha karena mereka cenderung mendiskusikan mengenai langkah usaha yang perlu ditempuh sebelum mengambil suatu keputusan atau resiko dan mahasiswa sangat yakin bahwa resiko merupakan tantangan dalam mengembangkan usaha karena mereka banyak memperoleh banyak pengalaman berwirausaha melalui sharring pendapat dengan teman yang sudah melakukan usaha.

5. Percaya diri dalam indikator ini menunjukkan mahasiswa memiliki keyakinan yang tinggi untuk berwirausaha karena mereka mau bertanya serta mempelajari lebih dalam lagi mengenai ilmu kewirausahaan dan mahasiswa memiliki sikap positif yang tinggi untuk memulai usaha karena mereka beranggapan untuk memulai suatu usaha harus terlebih dahulu memahami sikap berwirausaha yang sesungguhnya.

Berdasarkan pembahasan tersebut untuk mencapai sikap berwirausaha yang tinggi perlu melalui peningkatan pendidikan kewirausahaan dan pengalaman berwirausaha baik mahasiswa laki - laki maupun perempuan.

Hasil uji $\mathrm{F}$, nilai $\mathrm{F}$ hitung yang dihasilkan sebesar 23,892 lebih besar F tabel sebesar 8,56 dengan nilai signifikasi 0.00 lebih kecil dari 5\%. Adapun pengaruh ketiga varibel bebas yaitu pendidikan kewirausahaan $\left(\mathrm{X}_{1}\right)$, pengalaman berwirausaha $\left(\mathrm{X}_{2}\right)$, dan jenis kelamin (D) terhadap variable terikat yaitu sikap berwirausaha (Y) secara simultan berkontribusi sebesar $42 \%$ sedangkan $58 \%$ dipengaruhi oleh varibel lain diluar varibel yang diteliti.

Hasil statistik menunjukkan adanya pengaruh pendidikan kewirausahaan $\left(\mathrm{X}_{1}\right)$, pengalaman berwirausaha $\left(\mathrm{X}_{2}\right)$, dan jenis kelamin (D) terhadap sikap berwirausaha (Y) ditunjang dengan hasil penelitian dari beberapa ahli yaitu; hasil penelitian Jones et al (2011) menyatakan terdapat pengaruh antara pendidikan kewirausahaan, pengalaman berwirausaha, dan jenis kelamin terhadap sikap 
berwirausaha pada lulusan mahasiswa polandia yang dibuktikan dalam mencetak lulusan yang berkualitas dalam bidang kewirausahaan. Hasil penelitian Matlay (2008) menyatakan bahwa pendidikan kewirausahaan juga memberikan manfaat kepada mahasiswa dalam mengembangkan pengetahuan kewirausahaan, selain itu adanya pengalaman serta diskusi antara mahasiswa laki - laki dan perempuan juga berpengaruh terhadap sikap berwirausaha mereka.

Hasil penelitian Politis (2008) pemahaman yang mengenai pendidikan kewirausahaan, pengalaman, dan jenis kelamin berpengaruh terhadap sikap berwirausaha yang bertujuan pengembangan potensi yang dimiliki secara terukur dan terarah. Hasil penelitian Harris \& Gibson (2008) menyatakan bahwa pendidikan kewirausahaan, pengalaman berwirausaha, dan antara siswa laki-laki dan perempuan memiliki inovasi dam kreativitas yang berbeda satu sama lain yang berhubungan dengan sikap kewirausahaan.

Hasil temuan pada variabel pendidikan kewirausahaan mendapat sumbangan terendah dari indikator kedua yaitu sarana dan prasarana, karena mahasiswa kurang memaksimalkan sarana dan prasarana yang disediakan oleh kampus. Selain itu hasil temuan pada variabel pengalaman berwirausaha dengan indikator terendah yaitu lingkungan pendidikan, karena mahasiswa kurang memaksimalkan informasi mengenai ilmu kewirausahaan baik yang diajarkan dalam bentuk teori maupun praktek. Adapun hasil temuan variabel jenis kelamin memiliki kekurangan yaitu mahasiswa laki - laki kurang memiliki motivasi dalam berwirausaha daripada mahasiswa perempuan

Berdasarkan pembahasan tersebut untuk mencapai sikap berwirausaha yang tinggi perlu melalui peningkatan pendidikan kewirausahaan, peningkatan pengalaman berwirausaha, dan mahasiswa laki - laki maupun perempuan harus dapat mengembangkan kemampuan mereka dalam berwirausaha.

\section{SIMPULAN}

Berdasarkan hasil penelitian dan pembahasan yang diuraikan, maka diatas dapat disimpulkan bahwa pendidikan kewirausahaan berpengaruh terhadap sikap berwirausaha mahasiswa Fakultas Ekonomi Universitas Muhammadiyah. Temuan pada variabel pendidikan kewirausahaan yaitu mahasiswa kurang dapat memaksimalkan penggunaan sarana dan prasarana belajar yang disediakan kampus. Selain itu didukung temuan variabel sikap berwirausahayaitu mahasiswa kurang dapat menyelesaikan tugas yang diberikan secara baik dan benar, selain itu pengalaman berwirausaha berpengaruh terhadap sikap berwirausaha mahasiswa Fakultas Ekonomi Universitas Muhammadiyah. Temuan pada variabel pengalamanyaitu mahasiswa kurang dapat memaksimalkan dalam menggali pengetahuan ilmu kewirausahaan di lingkungan kampus. Selain itu didukung temuan variabel sikap berwirausahayaitu mahasiswa kurang dapat menjalankan usaha dengan baik dan benar. Dilanjutkan perbedaan sikap kewirausahaan antara mahasiswa laki - laki dan perempuan Fakultas Ekonomi Universitas Muhammadiyah menunjukkan bahwa mahasiswa laki - laki kurang termotivasi untuk berwirausaha daripada mahasiswa perempuan. Selain itu didukung temuan variabel sikap berwirausaha yaitu mahasiswa kurang dapat menyelesaikan tugas dan menjalankan usaha dengan baik dan benar. Pendidikan kewirausahaan, pengalaman berwirausaha, dan jenis kelamin berpengaruh terhadap sikap 
berwirausaha mahasiswa Fakultas Ekonomi Universitas Muhammadiyah. Hasil temuan menjelaskan secara bersama - sama mahasiswa laki - laki maupun perempuan kurang dapat memaksimalkan penggunaan sarana dan prasarana belajar yang disediakan kampus sehingga mereka kurang dapat menggali pengetahuan ilmu kewirausahaan di lingkungan kampus. Hal ini menyebabkan mahasiswa kurang dapat menyelesaikan tugas dan menjalankan usaha dengan baik dan benar.

\section{DAFTAR RUJUKAN}

Amine \& Staub. 2009."Women entrepreneurs in Sub-Saharan Africa: an institutional theory analysis from a social marketing point of view". Journal of Taylor Francis. Pp.183 -211

Badan Pusat Statistik. 2005. Data Tingkat Pengangguran. Jakarta : BPS

Basu, A .,Virick. 2007. “Assessing Entrepreneurial Intentions Amongst Students: A Comparative Study". http://nciia.org/conf08/assets/pub/basu2.pdf accessed diakses 5 April 2010.

Bohner. and Wanke. 2001. Attitudes and Attitude Change. Florence. KY: Psychology Press.

Borasi. and Finnigan. 2011. "Entrepreneurial attitudes and behaviors that can help prepare successful change agents in education". Journal of Taylor \& Francise. Vol.6 No. 1, pp.1 -29

Carey, Charlotte. and Naudin, Annette. 2006. "Enterprise Curriculum for Creative Industries Students : An Exploration of Current Attitudes and Issues". Education + Training, Vol . 48 No. 7, pp.518- 531 .

Davey, Todd., Plewa, Carolin., Stuwig, Miemie. 2011.'Entrepreneurship Perceptions and Career Intentions of International Students". Education + Training, Vol. 53 No. 5, pp.335 - 352.

Furdas. and Kohn. 2010. "What's the difference?! gender, personality, and the propensity to start a business". http://ssrn.com/abstract $=1560905$

Gallant, Monica., Majumdar, Sudipa ., Varadarajan, Damodharan. 2010."Outlook of female students towards entrepreneurship: An analysis of a selection of business students in Dubai". Education, Business and Society: Contemporary Middle Eastern Issues. Vol. 3 No.3, pp. 218 - 230

Gibson, S., Harris, M.L., Burkhalter, T.M. 2011. "Comparing the entrepreneurial attitudes of university and community college students". Journal of Higher Education Theory and Practice. Vol.11 No.2. pp.11-17.

Gurbuz, G. and Aykol, S. 2008. "Entrepreneurial intentions of young educated public in Turkey". Journal of Global Strategic Management. Vol. 4 No. 1

Harris, M.L. 2008. Examining the entrepreneurial attitude of business students: the impact of participation in the small business institude. Journal East Carolina University.

Harris, M. L. and Gibson,S.G. 2008. "Examining The Entrepreneurial Attitudes of US Business Students". Education + Training, Vol. 50 No.7, pp.568 - 581

Hegarty. (2006). "It's not an Exactscience: Teaching Entrepreneurship in Northern Ireland". Education + Training, Vol . 48 No. 5, pp.322 - 335

Heilman, M.E. and Chen, J.J. 2003."Entrepreneurship As a Solution: The Allure of Self Employment for Women and Minorities". Human Resource 
Management Review. Vol.13 No. 2, pp. 347-364.

Hisrich and Peters. 1998. Kewirausahaan. Bandung :Alfabeta.

Izedonmi, Famous., Okafor, Chinonye. 2007. "Assessment Of The Entrepreneurial Characteristics And Intentions Among Academics". Global Journal of Management and Business Research. Vol. 10 pp. 49 - 60.

Jones, Paul., Miller, Christopher., Jones, Amanda., Packham, Gary., Pickernell, David., Zbierowski, Przemyslaw. 2011. "Attitudes and Motivations of Pollish Students Towards Entrepreneurial Activity". Education + Training. Vol . 53 No. 5 , pp. $416-432$.

Kourilsky, M.L. and Walstad,W.B.1998. Entrepreneurship and Female Youth: Knowledge, Attitude, Gender Differences, and Educational Practices. Journal of Business Venturing.

Kundu, S.C. and Rani, Sunita. 2008. "Human resources entrepreneurial attitude orientation by gender and background: a study of Indian Air Forcetrainees. Entrepreneurship". Innovation and SMEsand Policy and Organisational Management. Vol. 5 No. 1

Lee and Wong. 2003. "Attitude Towards Entrepreneurship Education and New Venture Creation". Journal of Intrepresing Culture. Vol. 11 No 4.

Lestari, R.B. dan Wijaya, Trisnadi. 2012. "Pengaruh Pendidikan Kewirausahaan Terhadap Minat Berwirausaha Mahasiswa di STIE MDP, STMIK MDP, dan STIE MUSI. Jurnal Ilmiah STIE MDP”. Forum Bisnis Dan Kewirausahaan. Vol. 1 No. 2.

Lewis, Kate. and Massey, Claire. 2003."Delivering Enterprise Education in New Zealand". Education + Training, Vol . 45 No.4 pp.197-206.

Matlay 2008. "The impact of entrepreneurship education on entrepreneurial outcomes". Journal of Small Business and Enterprise Development. Vol . 15 No. 2, pp.382 - 396

Nuskhi, Muhammad. dan Setiana, Lucie. 2004. "Faktor yang mempengaruhi sikap kewirausahaan kelompok peternak sapi perah di Kabupaten Banyumas". Jurnal pembangunan pedesaan. Vol. 4 No.3, hal. 17-20.

Packham, Gary., Jones, Paul., Miller, Christopher., Pickernell, David., Thomas, Brychan. 2010. "Attitudes towards entrepreneurship education: a comparative analysis".Education + Training. Vol.52 No. 8, pp.568 - 586 .

Program Mahasiswa Wirausaha (PMW). 2015. Penerapan pendidikan kewirausahaan di Perguruan Tinggi (Buku pedoman). Direktorat jenderal pembelajaran dan kemahasiswaan Kementerian Riset, Teknologi, Dan Pendidikan Tinggi.

Petridou, Eugenia. and Glaveli, Niki. 2008. "Rural women entrepreneurship within cooperatives : training support". Gender in management: an international journal. Vol . 23 No. 4, pp. $262-277$.

Petridou, Eugenia., Sarri, Aikaterini., Kyrgidou, L.P. 2009. "Entrepreneurship Education In Higher Educational Institutions : The Gender Dimension". Gender in Management: An International Journal. Vol .24 No.4, pp.286 309.

Politis, Diamanto. 2008. "Does Prior Start-up Experience Matter for Entrepreneurs' Learning?: A Comparison Between Novice and Habitual Entrepreneurs". Journal of Small Business and Enterprise Development.. Vol.15 No.3 pp.472 - 489 . 
Saroni, Mohammad. 2012. Mendidik \& Melatih Entrepreneur Muda. Jakarta: Arus Media.

Sascha, Walter., Dirk, Dohse. 2009. The Interplay Between Entrepreneurshi $P$ Education And Regional Knowledge Potential Informing Entrepreneurial Intention. Working paper diakses 16 Nopember 2011.

Souitaris, V., Zerbinati, S., Andreas, A.L. 2007. "Do Entrepreneurship Programmes Raise Entrepreneurial Intenion of Science and Engineering Students? The Effect of Learning, Inspiration and Resources". Journal of Business Venturing,Vol. 22 No.4, pp. 566-591.

Sowmya, D.V., Majumdar, Sudipa., Gallant, Monica. 2010. "Relevance of Education for Potential Entrepreneurs : an International Investigation". Journal of small business and enterprise development. Vol . 17 No. 4, pp. $626-640$.

Sugiyono. 2013. Metode Penelitian Pendekatan Kuantitatif, Kualitatif, dan R\&D. Bandung: ALFABETA.

Suharti, Sirine. 2011. "Faktor-Faktor yang Berpengaruh Terhadap Niat Kewirausahaan (Entrepreneurial Intention) (Studi Terhadap Mahasiswa Universitas Kristen Satya Wacana, Salatiga”. Jurnal Manajemen dan Kewirausahaan. Vol.13 No. 2, pp.124-134.

Tung, L.C. 2011. The Impact of Entrepreneurship Education on Entrepreneurial Intention of Engineering Students City. University of Hong Kong.

Wibowo, Agus. 2011. Pendidikan kewirausahaan (Konsep dan strategi), Yogyakarta: Pustaka Pelajar.

Wijaya, Trisnadi. 2008, "Kajian model empiris perilaku berwirausaha UKM DIY dan Jawa Tengah", Jurnal manajemen dan kewirausahaan. Vol.10 No.2, hal.93-104.

Zhao, Fang. 2005. "Exploring the synergy between entrepreneurship and innovation". International Journal of Entrepreneurial Behavior \& Research. Vol.11 No.1, pp.25 - 4. 